\section{ИНТЕГРАЦИЯ МЕТОДОВ ЗФФЕКТИВНОГО УПРАВЛЕНИЯ ЛРОМЫШЛЕНЫМ ПРЕДПРИЯТИЕМ НА ПРИНЦИПАХ БЕРЕЖЛИВОСТИ}

Установлена по частоте упоминаний специалистами совокупность наиболее признанных методов бережливого производства. Раскрыта уместность их отдельного внедрения через достижение результата практического использования. Обоснованно сочетание методов в различных комбинациях для эффективного управления производственными мощностями, материальным потоком и документооборотом и внутренними регламентами промышленного предприятия. Обоснованны виды синергии как результат усиления действия отдельных методов в различном сочетании.

Ключевые слова: бережливое производство, метод бережливого производства, интеграция методов, эффект синергии, промышленное предприятие

Kolos Iryna, PhD, Associate Professor, Certified Accounting Practitioner, Department of Accounting and Auditing, National University of Food Technologies, Kyiv, Ukraine, e-mail:irynakolos2016@gmail.com, ORCID: http://orcid.org/0000-0001-7134-1441

\title{
Kuzmin 0., RESEARCH OF SCIENTIFIC ACTIVITIES Zhuk L. IN HIGHER EDUCATIONAL INSTITUTIONS: PLANNING, ORGANIzATION, CONTROL, REGULATION
}

Проведено аналіз особливостей провадження наукової діяльності у вищих навчальних закладах України, що належать до сфери управління Міністерства освіти і науки України, у контексті основних функиій менеджменту - планування, організування, контролювання та регулювання. Сформульовано пропозииї для ї̈ удосконалення з метою забезпечення формування $і$ досягнення основних цілей вищих навчальних закладів.

Ключові слова: вищі навчальні заклади, наукова діяльність, планування, організування, контролювання, регулювання.

\section{Introduction}

Higher educational institutions, like any other socioeconomic organizations, show different effectiveness. The stability of their functioning and development largely depends on the quality of management and actions of all employees [1, 2]. That is why the activity of higher educational institutions in general and, in particular, its scientific activity is important to consider in the context of the main provisions of management. General management functions - planning, organization, motivation, control, regulation - through specific and with the help of unifying functions are involved in all administrative processes of scientific activity of higher educational institutions. The analysis of the effectiveness of the implementation of these functions promotes an understanding of the processes in the sphere of the production of scientific activity of higher educational institutions and is extremely important for making managerial decisions with a view to improving it.

\section{The object of research and its technological audit}

The objects of research are higher educational institutions (universities, academies, institutes), belonging to the sphere of administration of the Ministry of Education and Science of Ukraine.

\section{The aim and objectives of research}

The aim of research is review and analysis of the basic principles of scientific activities in higher education institutions, develop proposals for its improvement.

To achieve this aim, the following main tasks are identified:

1. To conduct an analysis of the planning of scientific activities of leading universities in Ukraine, taking into account the main directions of its production.

2. To analyze the features of the organization and control of scientific research in universities of Ukraine in accordance with the current legislation.

3. To formulate proposals for improving planning, organizing, monitoring scientific activities.

\section{Research of existing solutions of the problem}

The publication of many scientists [3-8] is devoted to the study of the issue of scientific activity in higher educational institutions of Ukraine. So, in [3] examples of organizational and functional forms of universities of the advanced countries of the world are given, they receive a considerable amount of scientific and scientific-applied results. The study [4] considers the features of functioning in universities of such organizational forms as scientific and pedagogical research groups and scientific schools, which form a favorable innovation environment for universities. 
The essence, content, peculiarities of scientific research in Ukrainian universities are reflected in works [5, 6]. The authors [7, 8] note the special role of science and scientific research for modern universities.

Taking into account that modern universities operate under conditions (economic, legislative, regulatory), the issue of conducting scientific activities requires constant study and analysis in order to identify current problems and determine the prospects for further development.

\section{Methods of research}

The methods of analysis and synthesis, logical generalization, comparative comparison are used to solve the problems.

\section{Research results}

In accordance with Article 26 of the Law of Ukraine «On Higher Education» higher educational institutions conduct scientific activities by conducting scientific research, ensuring creative activity of participants in the educational process, training highly qualified scientific personnel and using the obtained results in the educational process [9]. Therefore, analyzing the scientific activity of higher educational institutions, it is necessary to take into account all these directions as components of a common system, each of which plays a certain, definite role and interacts with other components to achieve a specific goal.

A systematic approach to the production of scientific activity provides, first of all, the formation of common orientations of higher educational institutions in this field, the definition of prospects, final results, and ways and means to achieve them. Instrumental feasibility of this approach is strategic and tactical planning.

In accordance with the Laws of Ukraine «On Higher Education» and «On Scientific and Scientific and Technical Activities» $[9,10]$, higher educational institutions develop a strategy and perspective directions of educational, scientific and innovative activities. The strategy of development of scientific activity is an integral part of the overall strategy of higher educational institution, and the basis for the formation of tactical activities.

Analysis of the information presented on the official websites of the leading universities, included in the top ten according to the results of the consolidated rating of 2017 [11], shows the existence of strategic documents strategies and development programs, formed for 5-10 years. However, in their structure and essential content, these documents have certain drawbacks. Thus, in the strategies (programs) of individual higher educational institutions, the goals, objective and expected results have been defined, but mechanisms and measures for implementing this strategy have not been formulated, measures to monitor its implementation have not been reflected (Ivan Franko National University of Lviv, Yu. Fedkovych Chernivtsi National University). The strategies (programs) of a number of universities (such as the Taras Shevchenko National University of Kyiv, Ivan Franko National University of Lviv, Sumy State University, Yu. Fedkovych Chernivtsi National University) do not contain specific forecast values of indicators for which to monitor the strategy (program) during its implementation and evaluate the results after the completion of the planned period. In the documents of such universities as, for example, National Technical
University of Ukraine «Igor Sikorsky Kyiv Polytechnic Institute», the expected results for individual tasks have only a declarative nature: for example, «an increase in the number of scientific results obtained world-class», «an increase in the number of publications of university students»; or reflect a percentage increase in indicators without specifying specific baselines: for example, «increasing access to electronic library databases and resources outside Ukraine by $15-20 \% »$. The most elaborated document is the «Development Program of the V. N. Karazin Kharkiv National University for 2010-2020», which contains the specific measures necessary for the implementation of the main tasks, the indicators of each of the activities, and the forecast values of the indicators within the planned period.

In order to achieve the goals set forth in the strategic documents of universities (including those in the direction of scientific activity), it is advisable to finalize these documents for compliance with the basic principles of strategy formation, as well as the development of so-called university development road maps (indicating activities, performers, indicators, resources, risks, etc.).

The list of the main directions of scientific research, which defines and approves the academic council of the university, also belongs to the documents of a strategic nature of university. The list is formed in accordance with the Law of Ukraine «On Priority Directions for the Development of Science and Technology» [12] and the Decree of the Cabinet of Ministers of Ukraine «On the approval of the list of priority thematic areas of scientific research and scientific and technical developments» [13]. In determining the main areas of scientific research, the academic council of the university takes into account the scientific directions of the institutes (faculties) and departments, their scientific potential, the effectiveness of international cooperation, the performance of scientific and technical works commissioned by enterprises, the availability of scientific schools for scientific directions and the like.

One of the important aspects of strategic planning of scientific activity in the university is planning in the field of training highly qualified personnel. Lviv Polytechnic National University is the only university in Ukraine, which has been implementing this practice for a long time. Since the beginning of the 1990s, five and seven-year «Comprehensive programs for the training of scientific and scientific-pedagogical personnel» are being formed at the university. The programs summarize the plans of 16 educational and scientific institutes with the indication of specific quantitative indicators for the preparation of applicants for the degree of candidate and doctor of sciences, applicants for higher education of the degree of Doctor of Philosophy and Doctor of Science, admission to postgraduate and doctoral studies, transfer of research staff, development of a network of specialized academic councils. As a result of the planning and implementation of training of scientific and scientific-pedagogical personnel within the framework of the Comprehensive Program, achievement and retention of the staff of the highest qualification in the total number of faculty at the level of 65-70\% during 2004-2017, achievement of high performance indicators of doctoral and postgraduate studies - respectively, 85 and $67 \%$. In terms of the effectiveness of doctoral studies and postgraduate studies, Lviv Polytechnic National University is among the leaders among universities in Ukraine. 
Tactical (current) planning of the scientific activity of the university is carried out in accordance with the above-mentioned documents of a strategic nature. The scheme for planning the scientific activity of the university is shown in Fig. 1.

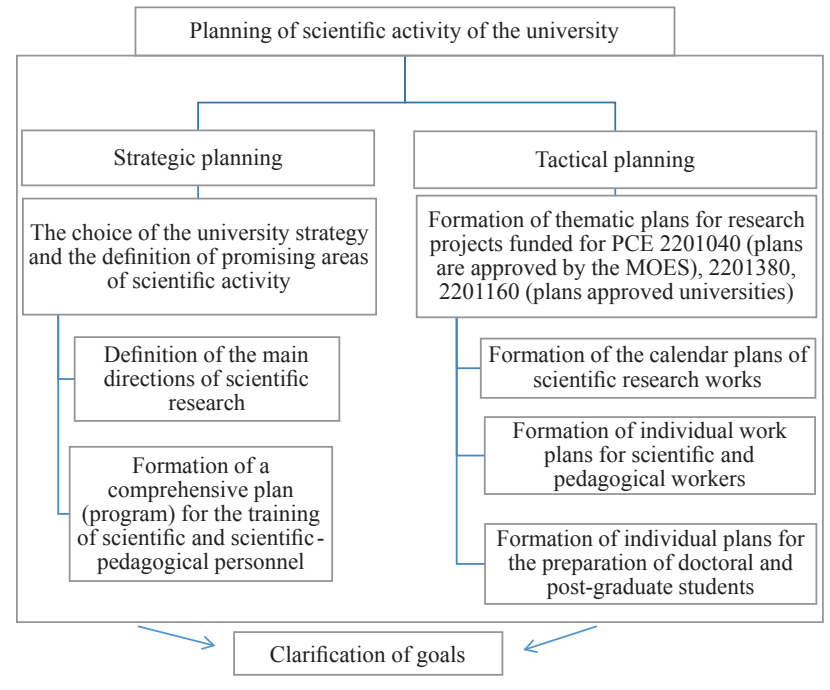

Fig. 1. Planning the scientific activity of the university

The current planning of scientific activity is realized through the formation of thematic plans for scientific research (for one year). There are:

- a thematic plan of research, financed by the Ministry of Education and Science of Ukraine on the code of the program classification of expenses (PCE) of the budget 2201040 «Research, scientific and technical development, implementation of works under state target programs and state order, training of scientific personnel, financial support of scientific infrastructure, scientific press and scientific objects that make up the national treasure, provision of activities of the State Fund for Fundamental Research». Thematic plan is approved by the Ministry of Education and Science of Ukraine. This plan includes all scientific researches that will be implemented this year at the expense of the general fund of the state budget, and in which universities is the executing organization;

- a thematic research plan funded by the Ministry of Education and Science of Ukraine for PCE 2201380 «Implementation of Ukraine's commitments in the sphere of international scientific and technical cooperation», on PCE 2201160 «Training of higher educational institutions of the III and IV levels of accreditation and provision of their practice bases», as well as other PCEs The thematic plan is approved by the rector of the university, which reflects all scientific works that will be implemented in universities this year within the working time of teachers and who are registered in the established order in Ukrainian institute of scientific and technical expertise and information. Scientific works in international projects are also included in the thematic plan.

For each scientific work included in the thematic plans, a work schedule is established, indicating the stages of work, the deadline for each stage and the expected results.

The scientific work of each teacher is planned for the next academic year and is reflected in his individual work plan. The list of works that can be provided for in an individual plan is presented in Table 1.

Planning is an important stage in the implementation of the scientific activity of the university, as it enables to streamline actions to achieve the goal: to link and systematize goals, tasks, activities, indicators and results and to identify problems in the process of achieving this goal.

The next stage is the organization of scientific activities, which consolidates the powers, tasks and responsibilities of employees in various divisions and at different levels of management [1].

Table 1

The list of the main types of scientific work of scientific and pedagogical workers of higher educational institutions [14]

\begin{tabular}{|c|l|}
\hline No. & \multicolumn{1}{|c|}{ Type of work } \\
\hline 1 & $\begin{array}{l}\text { Implementation of planned scientific research with reporting in the } \\
\text { following forms: } \\
\text { - scientific and technical report; } \\
\text { - thesis (doctoral, candidate); } \\
\text { - monograph; } \\
\text { - textbook, dictionary, reference book; } \\
\text { - scientific article in journals, refereed publications, other publications; } \\
\text { - application for the issue of titles of protection; } \\
\text { - abstracts of the report at conferences, symposia, seminars }\end{array}$ \\
\hline 2 & $\begin{array}{l}\text { Reviewing of monographs, textbooks, teaching aids, dictionaries, } \\
\text { reference books, thesis, author's abstracts, scientific articles, scientific } \\
\text { projects, thematic plans and the like }\end{array}$ \\
\hline 3 & $\begin{array}{l}\text { Finalization for the reissue of monographs, textbooks, teaching aids, } \\
\text { dictionaries, reference books }\end{array}$ \\
\hline 4 & $\begin{array}{l}\text { Management of scientific work of students with preparation: } \\
\text { - scientific article; } \\
\text { - applications for the issuance of titles of protection; } \\
\text { - works for the competition; } \\
\text { - reports to the conference }\end{array}$ \\
\hline
\end{tabular}

Scientific research in universities is carried out at the departments of educational and scientific institutes, in scientific divisions, as well as within doctoral and postgraduate courses. Accordingly, scientific and research workers and students, researchers, doctoral students, and graduate students are involved in scientific research.

Scientific and pedagogical workers carry out scientific activity (according to Article 53 of the Law «On Higher Education») within the basic working time. This time is 36 hours per week, 1512 hours per year (the annual working time can vary depending on the number of holidays) and the maximum teaching load per one rate can't exceed 600 hours per academic year. The difference between these time indicators is the time allocated to other types of work (and primarily to scientific work), provided for in the individual work plan. An important component of the individual work plan is to guide the scientific work of students in their free time. Responsible for organizing and performing scientific research at the departments are the heads of the departments.

The research work of students is an important component of the scientific activity of the university and an important factor in ensuring the training of qualified specialists. The research work of students is carried out: within the educational process and during their free time (Fig. 2).

For the successful implementation of student research works and ensures its effectiveness, it is important to upto-date such basic organizational principles and foundations: high science qualification, the possibility of students' 
abilities and interests, reality of subjects, the diversity of methods of work.

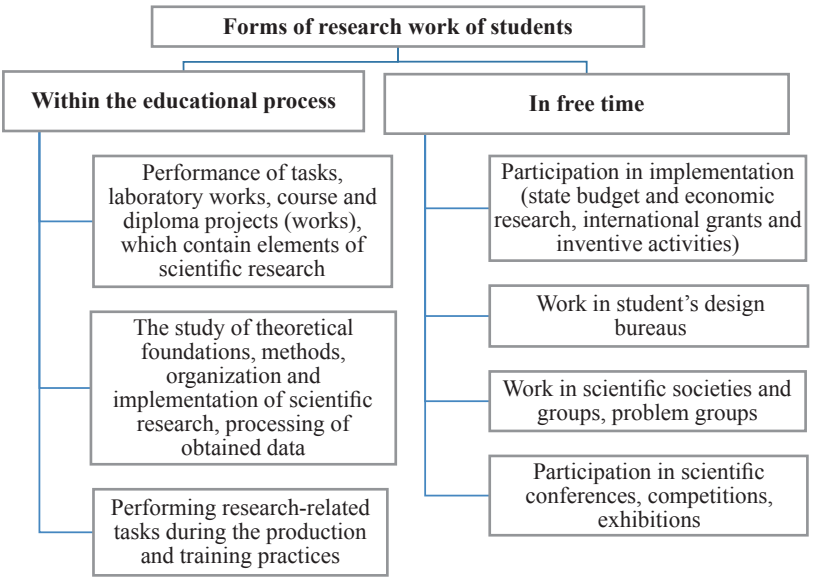

Fig. 2. Forms of research work of students

For organization and coordination of scientific and scientific and technical activities, the implementation of scientific research in universities, which subordinate to the Ministry of Education and Science of Ukraine, scientific research units (SRU), scientific research sectors, research institutes, scientific departments [15] are created. The activities of these units are regulated by a separate Regulation (for example, Regulation on the research part). In their work they submit to the pro-rector on scientific work.

The composition of these structural units includes units directly engaged in research: scientific departments of faculties, institutes and departments (for example, the state budget groups and temporary creative teams), research institutes, research centers, research laboratories. Heads of such units are, respectively, the scientific leaders of state budget groups, creative teams, directors of research institutes, heads of laboratories. Employees of research units can be scientific, pedagogical and other employees who work in these units in combination and/or contracts of civil-legal nature, as well as full-time research and engineering and technical personnel, support staff.

In Fig. 3 shows the organizational structure of the research part of the example of Lviv Polytechnic National University, which is composed of all the units stipulated by the Regulations on the organization of the Ministry of Education and Science of Ukraine [15].

Among the duties of employees of scientific units: implementation of fundamental and applied research and development, scientific and technical developments, preparation and implementation of international projects; conclusion and performance of scientific and scientific and technical works (contracts) on the order of domestic and foreign enterprises, the publication of scientific articles; participation in the organization and conduct of scientific conferences and the like.

With the aim of organizing, providing and supporting the scientific and research activity, scientific and technical departments are being created. Employees of such departments can be scientific workers, engineering and technical workers, support staff and others. Their duties include, in particular: the organization of the first stage of the competition of projects of fundamental and applied research and scientific and technical (experimental) developments, monitoring the timely implementation of these scientific works in accordance with the terms of the contract, approved technical tasks, calendar plans; organizational support for the conclusion and implementation of contractual research, preparation of documents for the state registration of scientific research (in accordance with the procedure for state registration and accounting of open research, development and research projects and theses), formation of staffing tables, coordination of draft estimates and justification for the costs of the scientific works, formation of general draft estimates of the units of the research part; formation of statistical reports, information support and marketing support for completed research, preparation for participation in international, state, industry exhibitions, scientific conferences, and the like.

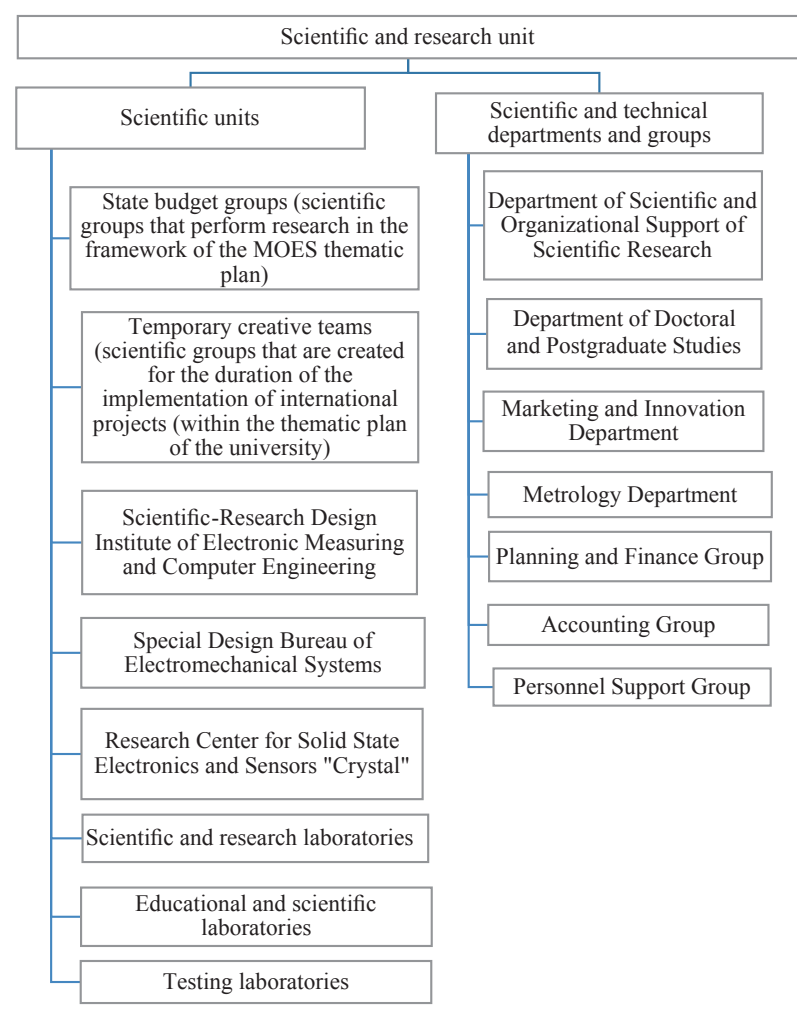

Fig. 3. The organizational structure of the scientific and research unit of Lviv Polytechnic National University

It is important to note that in the structure of SRU of Lviv Polytechnic National University in 2015, the Department of Marketing and Innovation is created - a unit, which has no analogues among the divisions of SRUs of the Ukrainian National Universities. For two years of work the department has proved expediency and necessity of the creation and functioning. Employees of the marketing and innovation department monitor the state of scientific research at the university, informational support and marketing support of scientific developments, participate in organizing the participation of the University in international and industry exhibitions. The effectiveness of the work of this unit is confirmed by the activation of scientific developments during the last two years. There is an increased interest in the results of scientific research of Lviv Polytechnic National University by foreign and domestic enterprises and business structures.

The effectiveness of the organization of scientific research and constant monitoring of their implementation 
ensure the effectiveness of tasks in the field of scientific activities. Control over scientific activity of scientific and pedagogical and scientific workers, as well as academic scientific departments of universities is carried out annually. This happens by:

- analysis of the implementation of individual work plans (scientific and other types of work) of teachers;

- rating of teachers and departments;

- conducting a comparative analysis of the scientific activities of university departments (institutes, faculties) according to the results of the annual reports of the departments. And taking appropriate measures to encourage effective units and employees, as well as to eliminate deficiencies and improve the results of units and workers with low efficiency.

An important element in the control of the scientific activity of scientific workers is the conduct of their attestation. According to [16], attestation determines the suitability of the qualification of the scientific employee of the position, assesses the effectiveness of his work, determines the need for upgrading skills and vocational training, determines measures to stimulate the professional level.

The issue of the effectiveness of scientific work of scientific and educational and scientific units is the subject of annual review at the meetings of the academic council of the university.

\section{SWOT analysis of research results}

Strengths. The strength of research is development of recommendations for improving the conduct of scientific activities in the university.

Weaknesses. The weak side in the study is the lack of a comparative analysis of the peculiarities of the organization of scientific research in various universities in Ukraine. This is due to the lack of relevant information on the official websites of individual universities.

Opportunities. Opportunities for further research is the analysis of the issue of motivating the professional activity of scientific and pedagogical and scientific workers as one of the general functions of management, which, together with planning, organizing, controlling and regulating, ensures the effectiveness of universities.

Threats. Threats to research results are changes in legislative and regulatory acts; these changes must be taken into account, in particular, in the organization and control of scientific activity.

\section{Conclusions}

1. Some shortcomings in strategic planning in leading universities - leaders on the basis of the consolidated ranking of universities in Ukraine are revealed. It is shown that correctly chosen and clearly formulated strategy and perspective directions of scientific activity, ensuring effective organization, execution and control over all processes in the sphere of production of scientific activity, and also their regulation enable universities to be competitive in the market of educational, scientific and scientific and technical services.

2. Positive experience in planning and organizing scientific activity is shown on the example of the «Lviv Polytechnic National University». Improving the planning, organization, conduct and control of scientific activities should be the subject of constant attention of the leadership of each institution, which aims to achieve a strategic goal and success. 3. Proposals on improving the effectiveness of the scientific activity of the university are formulated:

- improvement of the university's strategies in terms of formulating specific activities to achieve the goals and objectives, developing roadmaps for development of the university (indicating activities, executors, indicators, resources, risks, etc.);

- monitoring the implementation of strategies (programs);

- formation of «Comprehensive Programs for the Training of Doctors of Philosophy and Doctors of Sciences» and monitoring their implementation;

- realization of constant monitoring of the effectiveness of the work of educational, scientific and scientific units within the framework of thematic plans of universities in the context of the main directions of scientific research of universities in order to determine the feasibility of developing these areas of scientific research;

- improvement of organizational support for the scientific activity of universities, in particular, through the creation of marketing departments in the SRUs divisions;

- improvement of the reporting procedure of university departments on scientific activity by developing and implementing an appropriate automated system;

- accounting for the effectiveness of activities based on the results of rating the departments and reporting on scientific activities when considering organizational structure and optimizing the units of the university; - accounting results of the rating of teachers and researchers in making decisions on the conclusion of fixed-term employment contract.

\section{References}

1. Kuzmin, O. Ye. Osnovy menedzhmentu [Text]: Handbook / O. Ye. Kuzmin, O. H. Melnyk. - Kyiv: Akademvydav, 2007. - 462 p.

2. Kuzmin, O. Ye. Conceptual basis of management activities diagnostics in the system of process-structured management [Text] / O. Ye. Kuzmin, O. H. Melnyk, O. V. Mukan // Economics, Entrepreneuship, Management. - 2014. - Vol. 1, No. 1. - P. 15-24.

3. Horobets, Yu. I. Problema rozvytku ta reformuvannia nauky v universytetakh [Text] / Yu. I. Horobets, S. M. Porev // Zbirnyk naukovykh prats do 15-richchia APN Ukrainy «Pedahohichna i psykholohichna nauky v Ukraini». - Kyiv: Pedahohichna dumka, 2007. - Vol. 4. Pedahohika i psykholohiia vyshchoi shkoly. - P. 226-238.

4. Porev, S. M. Universytet i nauka [Text]: Monograph / S. M. Porev. Kyiv: Khimdzhest, 2012. - 384 p.

5. Strikha, M. V. Finansuvannia universytetskoi nauky: mizh ryzykamy stahnatsii i neperedbachuvanosti [Electronic resource] / M. V. Strikha // Dzerkalo tyzhnia. - 2016. - No. 1091. Available at: \www/URL: https://dt.ua/SCIENCE/finansuvannya-universitetskoyi-nauki-mizh-rizikami-stagnaciyi-i-neperedbachuvanosti- .html

6. Ilchenko, M. Yu. Nauka v universytetakh. Piatyrichnyi dosvid diialnosti Rady prorektoriv z naukovoi roboty vyshchykh navchalnykh zakladiv III-IV rivniv akredytatsii ta dyrektoriv naukovykh ustanov Ministerstva osvity i nauky Ukrainy [Text] / ed. by M. Yu. Ilchenko. - Kyiv: TOV «VD «EKMO», 2010. - 35 p.

7. Zghurovskyi, M. Doslidnytski universytety: shans dlia Yevropy [Electronic resource] / M. Zghurovskyi // Dzerkalo tyzhnia. 2006. - No. 618. - Available at: \www/URL: https://dt.ua/ EDUCATION/doslidnitski_universiteti_shans_dlya_evropi.html

8. Nikolaienko, S. M. Upravlinnia yakistiu vyshchoi osvity: teoriia, analiz i tendentsii rozvytku [Text]: Monograph / S. M. Nikolaienko. - Kyiv: Kyiv National University of Trade and Economics, 2007. - 519 p. 
9. Pro vyshchu osvitu [Electronic resource]: Law of Ukraine from July 1, 2014 No. 1556-VII. - Available at: \www/URL: http:/ zakon5.rada.gov.ua/laws/show/1556-18

10. Pro naukovu i naukovo-tekhnichnu diialnist [Electronic resource] Law of Ukraine from November 26, 2015 No. 848-VIII. - Available at: \www/URL: http://zakon3.rada.gov.ua/laws/show/848-19

11. Konsolidovanyi reitynh VNZ Ukrainy 2017 roku [Electronic resource] // Osvita.ua. - 2017. - Available at: \www/URL http://osvita.ua/vnz/rating/51741/

12. Pro priorytetni napriamy rozvytku nauky i tekhniky [Electronic resource]: Law of Ukraine from July 11, 2001 No. 2623-III. Available at: \www/URL: http://zakon5.rada.gov.ua/laws/show/ 2623-14

13. Pro zatverdzhennia pereliku priorytetnykh tematychnykh napriamiv naukovykh doslidzhen i naukovo-tekhnichnykh rozrobok na period do 2020 roku [Electronic resource]: Decree of the Cabinet of Ministers of Ukraine from September 7, 2011 No. 942. Available at: \www/URL: http://zakon2.rada.gov.ua/laws/show/ 942-2011-\%D0\%BF

14. Pro zatverdzhennia norm chasu dlia planuvannia i obliku navchalnoi roboty ta perelikiv osnovnykh vydiv metodychnoi, naukovoi y orhanizatsiinoi roboty pedahohichnykh ta naukovo-pedahohichnykh pratsivnykiv vyshchykh navchalnykh zakladiv [Electronic resource]: Order of the Ministry of Education and Science of Ukraine from August 7, 2002 No. 450. - Available at: \www/URL http://zakon3.rada.gov.ua/laws/show/z0698-02

15. Shchodo Polozhennia pro orhanizatsiiu naukovoi, naukovotekhnichnoi diialnosti u vyshchykh navchalnykh zakladakh III ta IV rivniv akredytatsii [Electronic resource]: Order of the Ministry of Education and Science of Ukraine from June 1 , 2006 No. 422. - Available at: \www/URL: http://zakon2.rada. gov.ua/laws/show/z1197-06
16. Pro zatverdzhennia Polozhennia pro atestatsiiu naukovykh pratsivnykiv [Electronic resource]: Decree of the Cabinet of Ministers of Ukraine from August 13, 1999 No. 1475. - Available at: \www/ URL: http://zakon2.rada.gov.ua/laws/show/1475-99-\%D0\%BF

\section{ИССЛЕДОВАНИЕ НАУЧНОЙ ДЕЯТЕЛЬНОСТИ В ВЫСШИХ УЧЕБНЫХ ЗАВЕДЕНИЯХ: ПЛАНИРОВАНИЕ, ОРГАНИЗАЦИЯ, КОНТРОЛЬ, РЕГУЛИРОВАНИЕ}

Проведен анализ особенностей осуществления научной деятельности в высших учебных заведениях Украины, которые принадлежат к сфере управления Министерства образования и науки Украины, в контексте основных функций менеджмента - планирования, организации, контроля и регулирования. Сформулированы предложения для ее усовершенствования с целью обеспечения формирования и достижения основных целей высших учебных заведений.

ключевые слова: высшие учебные заведения, научная деятельность, планирование, организация, контроль, регулирование.

Kuzmin Oleh, Doctor of Economic Sciences, Professor, Director of Institute of Economics and Management, Department of Management and International Business, Lviv Polytechnic National University, Ukraine, e-mail: oleh.y.kuzmin@lpnu.ua, ORCID: http:// orcid.org/0000-0002-6014-6437

Zhuk Liliya, PhD, Associate Professor, Head of Scientific Research Department, Lviv Polytechnic National University, Ukraine, e-mail: liliia.v.zhuk@lpnu.ua, ORCID: http://orcid.org/0000-0001-7299-2705

\section{Shysholin A. FUNCTIONING OF ENTREPRENEURIAL UNIVERSITIES AS SUBJECTS OF THE SYSTEM OF INTERNATIONAL KNOWLEDGE TRANSFER}

Проаналізовано основі підходи до поняття «підприємнищький університет», надано авторсъке визначення даного терміну. Досліджено міжнародний трансфер знань як систему. Визначено такі його складові: трансфер технологій, експорт освітніх послуг, інноваційна діяльність. За результатами дослідження визначено роль і місие підприємницького університету як суб'єкта системи міжнародного трансферу знань.

Ключові слова: підприємницький університет, міжнародний трансфер знань, ринок освітніх послуг, зовнішньоекономічна діяльність.

\section{Introduction}

In the context of the current development of higher education sphere, its «economization» and the entry into international markets of educational services, technology transfer and innovation, the problem of identifying an entrepreneurial university as a subject of the international transfer of knowledge system arises. Recently, more and more research universities shift over to the next development stage of an entrepreneurial university. That is why the leaders and managers of these universities need to be clearly oriented in the field of international transfer of knowledge as a system consisting of educational services and technology transfer. Thus, it should be carefully em- phasized on the main statutory type of activity for each university for each student, which is the provision of educational services. In addition, the chain beginning the term of educational service and its main characteristics to the term of the market of educational services as a system of economic relations with its inherent characteristics should be retraced.

\section{The object of research and its technological audit}

In the current conditions of reforming the higher education sphere in Ukraine and the gradual transition of national universities to the absolute autonomy, including a financial 